\title{
The response of East Kalimantan, Indonesia local rice cultivars against iron stress
}

\author{
NURHASANAH ${ }^{1, \bullet}$, HELMA SUCI LESTARI ${ }^{1}$, WIDI SUNARYO ${ }^{1}$ \\ Department of Agroecotechnology, Faculty of Agriculture, Universitas Mulawarman. Jl. Pasir Balengkong No.1 Kampus Gunung Kelua, Samarinda \\ 75119, East Kalimantan, Indonesia, Tel.: +62-541-749159, Fax.: +62-541-738341, `email: nurhasanah_2710@yahoo.com
}

Manuscript received: 16 November 2018. Revision accepted: 28 December 2018.

\begin{abstract}
Nurhasanah, lestari HS, Sunaryo W. 2019. The response of East Kalimantan, Indonesia local rice cultivars against iron stress. Biodiversitas 20: 273-282. Iron (Fe) toxicity is one of the most problematic metal elements in acidic soil. Besides being as an essential micronutrient, an excessive iron can cause mineral and nutrients absorption disorder which leads to disruption of plant metabolism and cell development. Reduction of plant growth and yield will be the further consequences of the excessive soil iron content. This study aimed to evaluate the response of East Kalimantan local rice cultivars and to screen rice genotypes tolerant to iron stress. Twenty-five rice genotypes were used in this study, consisted of twenty-three local rice cultivars of East Kalimantan and two control of iron sensitive (IR64) and tolerant (Mekongga) varieties. Uniform sprouts (3 days old) having 1-1.5 cm root length were used for iron stress experiment. The seedlings were grown in nutrient solution using hydroponic system in an aerobic condition. The seedlings were treated for one week in iron stress condition by adding an extra iron source of 100 and $200 \mathrm{ppm} \mathrm{FeSO}_{4} .7 \mathrm{H}_{2} \mathrm{O}$ ( $\mathrm{pH} 4.0$ ). The seedlings grown in the nutrient solution without an extra iron treatment at normal acidity growth condition ( $\mathrm{pH} 5.8$ ) were used as the control. The growth responses were observed from root, shoot, and biomass of the plants. The tolerance index of the plant growth characters was calculated to classify the rice genotypes into tolerant, moderate, and sensitive to iron stress. The results showed that 100 and $200 \mathrm{ppm}$ of FeSO4.7H2O treatments inhibited the root and shoot growth and also reduced the plant biomass. The plant growth reduction was in parallel with the increase of iron concentration. There was a significant differential response of East Kalimantan local rice genotypes to iron stress treatment. Some genotypes showed an extreme reduction of plant growth, whereas several genotypes had an increased growth under stressed situation. In the contrary, the sensitive genotype IR 64 was consistently sensitive based on the tolerance index of the root, shoot, and plant biomass characters. Among all growth parameters, the most selective character for iron toxicity screening was maximal root length character. This character caused the most severe symptoms for most of the genotypes. Two local rice genotypes, Bentian and Bogor Hitam, were consistently tolerant based on the maximal root growth, total root growth, shoot length and plant biomass.
\end{abstract}

Keywords: East Kalimantan, local rice, iron stress, iron-tolerant, tolerance index

\section{INTRODUCTION}

Soil acidity is a plant growth limiting factor causing significant yield reduction in the crop plants, including rice. Acid soil spreads widely, from lowlands to highlands. Acid soil is generally found in wet climates (high rainfall> 2,000 $\mathrm{mm}$ per year) and can be formed from various types of soil materials. Acidic land is characterized by low $\mathrm{pH}$, low cation exchange capacity (CEC), low nutrient content, low organic matter content, and excessive metal content (Sahrawat, 2004; Chérif et al. 2009).

One of the problematic metal elements in the acidic soil is iron $(\mathrm{Fe})$ toxicity. Actually, iron is an essential micronutrient playing a critical role in metabolic processes (Briat et al. 1995; Kim and Guerinot, 2007; Lan et al., 2011). Iron is also a cofactor for several important enzymes (Morrissey and Guerinot, 2009). However, excessive iron can be toxic to plants (Anjum et al. 2015; Tripathi et al. 2015). Iron toxicity will disrupt absorption of essential mineral nutrients in plants, which then further disrupt plant metabolism processes and cell development (Connolly and Guerinot, 2002; Rout and Sahoo, 2015). In severe condition, iron toxicity can cause abnormalities of growth, reduce yields, even crop failure and plant death (Audebert and Sahrawat, 2000; Curie and Briat 2003; Audebert and Fofana, 2009).

Several factors in the soil that can lead to iron poisoning include mineralogy (kaolinite), clay content, amount of soil exchangeable $\mathrm{Fe}$, soil acidity, poor and unbalanced nutrient content, and lack of root oxidation due to the accumulation respiratory-inhibiting materials (Sahrawat and Diatta, 1995; Dobermann and Fairhurst 2000). The critical limit of $\mathrm{Fe}$ concentration in the soil causing iron poisoning in rice is around $100 \mathrm{ppm}$ at $\mathrm{pH} 3.7$ and $300 \mathrm{ppm}$ or higher at $\mathrm{pH} 5.0$ (Sahrawat et al. 2000). According to Asch et al. (2005), toxic Fe content in the solution varies widely from 10-500 ppm Fe.

The use of iron-sensitive genotypes will severe the $\mathrm{Fe}$ poisoning symptoms in the plants, including rice. The negative effects of $\mathrm{Fe}$ poisoning can be reduced by environmental manipulation through water regulation (Yang et al., 2004), balanced fertilization (Ramirez et al., 2002), lime application (Jena et al. 2008), and soil amelioration (Nozoe et al. 2010). However, these treatments are difficult to be implemented as they are high cost, time-consuming and laborious. Therefore, the use of 
iron tolerant varieties is highly recommended for improving rice productivity in the affected areas.

East Kalimantan has been known as one of rice biodiversity spots in Indonesia having hundreds of local rice genotypes (Nurhasanah et al. 2016; Nurhasanah et al. 2017). Their genetic potency as genes sources for several important rice diseases have been previously reported (Nurhasanah et al. 2018); however, their response to abiotic stress, especially the iron toxicity tolerance, was limitedly known. In addition, several studies proposed that iron toxicity tolerance study might reflect potential impacts in alleviating the stresses of other metal ions in plants (Emamverdian, 2015; Tripathi et al. 2018). Therefore, this study was carried out to evaluate the response of East Kalimantan local upland rice cultivars as an early screening for iron stress tolerance in the seedling stage using a hydroponic system.

\section{MATERIALS AND METHODS}

\section{Plant materials}

Twenty-three local rice cultivars originated from Kutai Kartenegara District, East Kalimantan were screened for their tolerance to iron toxicity. The local rice cultivars consisted of 17 non-glutinous and six glutinous cultivars. An iron sensitive rice variety IR64 (Nugraha et al. 2016; Mackill and Khush 2018); and tolerant variety Mekongga (Suprihatno et al., 2009; Nurhasanah 2017) were also included in this study.

\section{Seeds germination}

The selected rice seeds were sterilized using $10 \%(\mathrm{v} / \mathrm{v})$ $\mathrm{NaOCl}$ for $15 \mathrm{~min}$, and rinsed with distilled water. The seeds were soaked for $24 \mathrm{~h}$ in deionized water at room temperature under dark condition. The rice seeds sinking in the water were then germinated on moisture germination paper for three days in room temperature $\left(28-31^{\circ} \mathrm{C}\right)$ under dark condition.

\section{Iron stress treatment}

A uniform sprouts having $1-1.5 \mathrm{~cm}$ root length were further used for iron stress experiment. The selected sprouts were grown in nutrient solution (Yoshida, 1976) using raft foam of $5 \mathrm{~mm}$ in height to prevent the seedlings from drowning in the hydroponic growth medium. The nutrient solution containing macronutrients $\left(\left(\mathrm{NH}_{4} \mathrm{NO}_{3}\right.\right.$, $\left.\mathrm{NaH}_{2} \mathrm{PO}_{4} .2 \mathrm{H}_{2} \mathrm{O}, \quad \mathrm{K}_{2} \mathrm{SO}_{4}, \quad \mathrm{CaCl}_{2}, \quad \mathrm{MgSO}_{4} .7 \mathrm{H}_{2} \mathrm{O}\right) \quad$ and micronutrients $\left(\left(\mathrm{NH}_{4}\right)_{6} \cdot \mathrm{Mo}_{7} \mathrm{O}_{24} \cdot 4 \mathrm{H}_{2} \mathrm{O}, \mathrm{MnSO} 4, \mathrm{H}_{3} \mathrm{BO}_{3}\right.$, $\left.\mathrm{ZnSO}_{4} .7 \mathrm{H}_{2} \mathrm{O}, \mathrm{CuSO}_{4} .5 \mathrm{H}_{2} \mathrm{O}, \quad \mathrm{FeSO}_{4} .7 \mathrm{H}_{2} \mathrm{O}\right)$ in deionized water was placed in plastic culture containers. The solution was maintained at $\mathrm{pH} 5.8$.

The seedlings were then treated in iron stress condition for one week. Iron stress condition was applied by adding an extra iron source compound of 100 and 200 ppm $\mathrm{FeSO}_{4} .7 \mathrm{H} 2 \mathrm{O}$ in the nutrient solutions at $\mathrm{pH} 4.0$. In the control treatment, the seedlings were grown in the nutrient solution without addition of extra iron (the nutrient solution contains iron according to the normal iron requirement concentration for rice seedlings in Yoshida solution) at normal acidity growth condition at $\mathrm{pH}$ 5.8. The $\mathrm{pH}$ of all experiments was constantly maintained daily. The nutrient solution in all experiments was not refreshed with the new nutrient until the last experiment. All experiment units were placed in a growth chamber with $16 \mathrm{~h}$ photoperiod in room temperature $\left(28-31^{\circ} \mathrm{C}\right)$. The experiment was repeated six times. The experiment was conducted in aerated condition.

\section{Plant growth observation}

Several root and shoot growth characters were observed to evaluate the response of the rice seedling against iron stress treatment. The shoot length (SL) was measured from the base of the shoot to the highest leaf tip. The maximal root length (MRL) was measured as the longest root growth (from the tip of root to the root base). The total root growth (TRG) was the sum of all seminal root length. Root number was counted for all seminal roots in the rice seedlings. Plant fresh and dry biomass were also observed.

\section{Data analysis}

Observed data of root, shoot and plant biomass were used to calculate tolerance index (TI) (Rout et al. 2014). The TI was calculated by dividing the growth in stress condition with the growth in normal condition. The TI value then was used to classify the tolerant level of the tested rice genotypes. Pearson correlation was used to analyze the correlation between MRL and TRG parameters.

The percentage of root and shoot growth reduction was calculated using the formula (Richard et al. 2015):

Growth reduction $\%=(($ Root or shoot growth in stress condition Root or shoot growth in normal condition) / Root or shoot growth in normal condition) X 100\%

\section{RESULTS AND DISCUSSION}

\section{Root growth}

In a normal growth condition, the root growth of the rice genotypes in this study differed since they represented the different genetic diversity. Several genotypes had short root length either the maximal length or total root growth as observed in Bogor Hitam, Buyung and Ketalun Tawar, and others had longer root length as in Jala Mengo, Ketan Lekatan and ketan Linjuang cultivars (Table 1). In iron stress condition, the root growth of most of genotypes was inhibited in an addition of 100 and $200 \mathrm{ppm}$ of $\mathrm{FeSO}_{4} .7 \mathrm{H} 2 \mathrm{O}$. The maximal root length (MRL) and the total root growth (TRG) were decreased compared to the control growth condition (Table 1). It means that iron concentration of $100 \mathrm{ppm}$ and $200 \mathrm{ppm}$ of FeSO4.7H2O at $\mathrm{pH} 4.00$ has been able to inhibit the growth of all rice genotype. According to Sahrawat et al (2000) Fe concentration at $100 \mathrm{ppm}$ could already be a toxic concentration to the rice plants. Several toxic iron concentrations were reported earlier showing that higher iron concentration increased the toxic effect to the plants (Asch et al 2005). Mild to severe iron toxicity symptom was observed in the presence of around 50 to $300 \mathrm{ppm}$ of 
iron in rice seedling (Noor et al 2012). In addition, the concentration of $\mathrm{Fe}$ in the soil which causes toxicity varies depending on the acidity of the soil solution (Sahrawat 2004).

The root growth reduction varied among the rice genotypes at different extra iron concentrations. Generally, the percentage of root growth reduction was higher when the iron stress concentration increased from 100 to 200 ppm either based on the MRL (Figure 1) or TRG (Figure 2) parameters. The highest root growth reduction in the MRL was $-31.33 \%$ in the $100 \mathrm{ppm}$ and $-38.52 \%$ in the $200 \mathrm{ppm}$ of $\mathrm{FeSO}_{4} .7 \mathrm{H} 2 \mathrm{O}$, observed in the control of sensitive genotype IR64. The same result was also noticed in the
TRG parameter, in which the root growth of genotype IR 64 decreased up to -38.30 and $-39.38 \%$ in the 100 and 200 ppm $\mathrm{FeSO}_{4} .7 \mathrm{H} 2 \mathrm{O}$, respectively. Root growth significantly interferes in the presence of metal ions. Therefore to quantify the inhibitory effect of iron or other metal ions, root growth was widely used to evaluate the response of the plants to that abiotic stress condition (Rout et al. 2014). Plants with iron poisoning have a small, rough, short and blunt root (Sahrawat 2004). However, several genotypes showed an opposite phenomenon, in which the root growth was increased in the toxic iron condition. These genotypes might have tolerant character against iron stress.

Table 1. Mean value of Maximal Root Length and Total Root Growth of the rice genotypes at a different $\mathrm{FeSO}_{4} .7 \mathrm{H} 2 \mathrm{O}$ concentration

\begin{tabular}{|c|c|c|c|c|c|c|c|c|}
\hline \multirow{2}{*}{ Id } & \multirow{2}{*}{ Geno-type } & \multirow{2}{*}{ Rice type } & \multicolumn{3}{|c|}{ Maximal root length (cm) } & \multicolumn{3}{|c|}{ Total root growth $(\mathrm{cm})$} \\
\hline & & & O ppm & 100 ppm & $200 \mathrm{ppm}$ & 0 ppm & $100 \mathrm{ppm}$ & 200 ppm \\
\hline $\mathrm{V} 1$ & IR 64 & Non-glutinous & 9.00 & 6.18 & 5.53 & 12.97 & 8.00 & 7.86 \\
\hline $\mathrm{V} 2$ & Mekongga & Non-glutinous & 8.85 & 6.55 & 6.27 & 13.63 & 13.60 & 13.40 \\
\hline V3 & Jala Mengo & Non-glutinous & 14.30 & 11.08 & 10.82 & 25.08 & 18.33 & 18.38 \\
\hline V4 & Mayas & Non-glutinous & 9.68 & 8.52 & 7.55 & 10.85 & 12.62 & 13.25 \\
\hline V5 & Kawit & Non-glutinous & 8.72 & 7.15 & 6.95 & 13.20 & 11.42 & 9.42 \\
\hline V6 & Awang & Non-glutinous & 9.60 & 9.54 & 10.57 & 16.55 & 13.98 & 12.07 \\
\hline V7 & Bentian & Non-glutinous & 9.88 & 9.13 & 9.00 & 13.67 & 17.02 & 14.43 \\
\hline V8 & Ritam & Non-glutinous & 10.95 & 8.18 & 8.15 & 12.88 & 10.77 & 11.28 \\
\hline V9 & Bogor Hitam & Non-glutinous & 6.47 & 8.03 & 8.60 & 8.22 & 11.22 & 10.20 \\
\hline V10 & Bogor Putih & Non-glutinous & 8.75 & 10.08 & 7.38 & 10.83 & 11.97 & 11.92 \\
\hline V11 & Sungkai & Non-glutinous & 8.80 & 7.30 & 6.95 & 10.30 & 9.67 & 14.62 \\
\hline V12 & Tumiyang & Non-glutinous & 7.78 & 5.62 & 5.22 & 18.30 & 13.68 & 13.60 \\
\hline V13 & Melak & Non-glutinous & 10.37 & 9.27 & 8.02 & 12.28 & 11.45 & 10.90 \\
\hline V14 & Bogor & Non-glutinous & 9.37 & 9.02 & 7.57 & 16.73 & 12.92 & 11.45 \\
\hline V15 & Mayas Kuning & Non-glutinous & 10.35 & 8.25 & 7.03 & 14.67 & 14.83 & 11.98 \\
\hline V16 & Mayas Putih & Non-glutinous & 11.62 & 10.65 & 8.43 & 14.98 & 18.70 & 12.37 \\
\hline V17 & Buyung & Non-glutinous & 7.97 & 9.08 & 8.83 & 9.78 & 11.73 & 10.40 \\
\hline V18 & Serai Gunung & Non-glutinous & 9.82 & 7.30 & 6.27 & 11.53 & 9.70 & 11.07 \\
\hline V19 & Ketalun Tawar & Non-glutinous & 7.67 & 9.57 & 7.65 & 7.67 & 10.35 & 10.82 \\
\hline V20 & Ketan Putih & Glutinous & 11.88 & 9.67 & 9.58 & 18.42 & 20.12 & 18.05 \\
\hline $\mathrm{V} 21$ & Ketan Huan & Glutinous & 7.75 & 6.72 & 5.70 & 10.83 & 10.37 & 12.57 \\
\hline V22 & Ketan Lekatan & Glutinous & 13.18 & 11.65 & 11.40 & 15.38 & 13.87 & 13.17 \\
\hline $\mathrm{V} 23$ & Ketan Putek Iting & Glutinous & 12.13 & 8.97 & 10.78 & 18.38 & 14.05 & 12.22 \\
\hline V24 & Ketan Mayang & Glutinous & 10.15 & 8.47 & 8.45 & 13.65 & 11.62 & 11.40 \\
\hline $\mathrm{V} 25$ & Ketan Linjuang & Glutinous & 13.90 & 11.98 & 11.93 & 20.18 & 17.87 & 16.95 \\
\hline
\end{tabular}
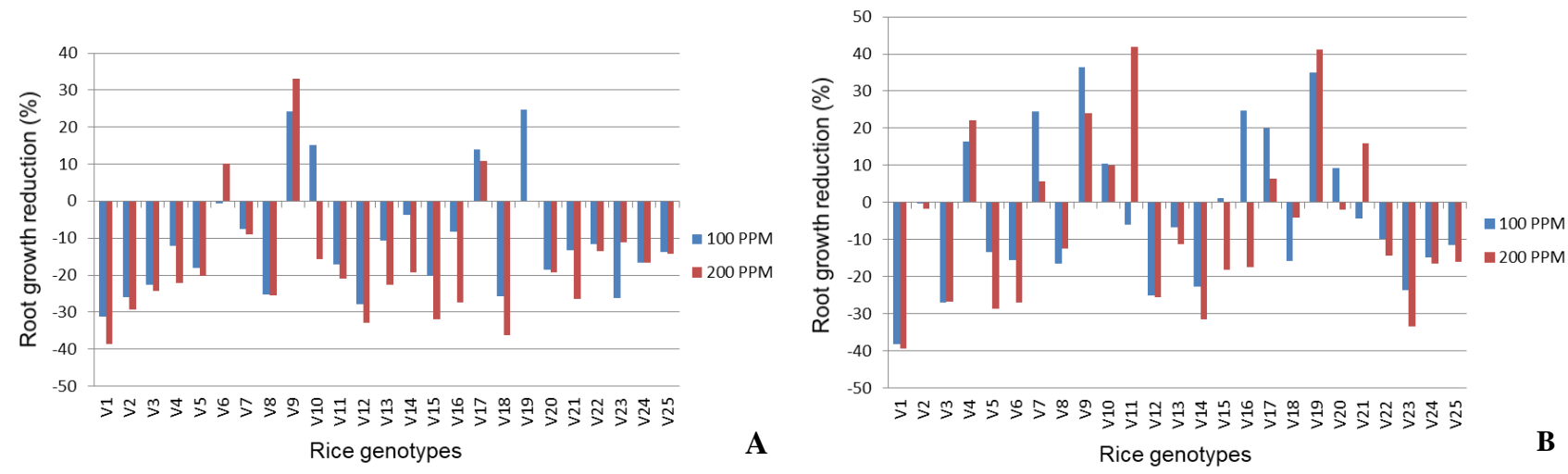

Figure 1. Percentage of the root growth reduction or accretion of the rice genotypes at different iron stress concentration. A. Maximal Root Length; B. Total Root Growth. V1 (IR 64), V2 (Mekongga), V3 (Jala Mengo), V4 (Mayas), V5 (Kawit), V6 (Awang), V7 (Bentian), V8 (Ritam), V9 (Bogor Hitam), V10 (Bogor Putih), V11 (Sungkai), V12 (Tumiyang), V13 (Melak), V14 (Bogor), V15 (Mayas Kuning), V16 (Mayas Putih), V17 (Buyung), V18 (Serai Gunung), V19 (Ketalun Tawar), V20 (Ketan Putih), V21 (Ketan Huan), V22 (Ketan Lekatan), V23 (Ketan Putek Iting), V24 (Ketan Mayang), V25 (Ketan Linjuang) 


\section{Root Tolerance Index (RTI)}

Root tolerance index (RTI) is one of the most important markers to screen genotypes and varieties for metal tolerance (Wu et al. 1997; Famoso et al. 2010), including iron (Rout et al. 2014). Tolerance index is considered very useful to characterize tolerant genotypes by comparing the growth data of different treatments and the control. It shows the level of growth reduction or accretion in the stressed condition compared to control/normal growth, meaning that the lower the tolerance index value, the more severe the plant growth as a result of the plant stress response, vice versa.

The RTI of the MRL ranged from 0.69 to 1.25 in 100 ppm $\mathrm{FeSO}_{4} .7 \mathrm{H} 2 \mathrm{O}$, and between 0.61 and 1.33 in the presence of $200 \mathrm{ppm}$ of $\mathrm{FeSO}_{4} .7 \mathrm{H} 2 \mathrm{O}$ (Table 2). The tolerance level was grouped based on the RTI value, in which the genotypes with RTI value lower than 0.7 were categorized as sensitive, larger than 0.9 as tolerant, and in between 0.7-0.9 are moderately tolerant (Wu et al. 1997). All of the local rice genotypes were grouped as moderately tolerant or tolerant at iron stress concentration of $100 \mathrm{ppm}$ $\mathrm{FeSO}_{4} .7 \mathrm{H} 2 \mathrm{O}$, while only two local rice genotypes "Mayas Kuning" and "Serai Gunung" were sensitive at 200 ppm of $\mathrm{FeSO}_{4} .7 \mathrm{H} 2 \mathrm{O}$. Among eight genotypes tolerant to $100 \mathrm{ppm}$ $\mathrm{FeSO}_{4} .7 \mathrm{H} 2 \mathrm{O}$, only five local rice genotypes were constantly tolerant in the $200 \mathrm{ppm}$ of the iron source. The iron-sensitive control genotype IR64 remained susceptible to iron in both of iron-stressed levels. On the other hand, Mekongga variety which was described as abiotic tolerant genotype, such as aluminum (Sari et al. 2013) and iron (Nurhasanah, 2017), was grouped as moderately tolerant to iron stress based on the maximal root length character.

A larger range of RTI value was observed when the tolerance index was applied for the TRG character (Table $3)$. There was a different tolerance level of several genotypes using RTI value from different character of MRL or TRG. For example, the moderately tolerant level shifted to tolerant as observed in Mekongga variety. In another situation, "Awang" cultivar which was tolerant based on the RTI value of MRL became moderate using the TRG parameter. Even, a drastically alteration from sensitive to tolerant category occurred in "Serai Gunung" cultivar. The different tolerance level of the genotypes, when screened using the MRL or TRG characters, might be due to the different response of the root growth in dealing with iron stress condition. Both characters might correlate with the plant's tolerance mechanisms against iron stress. However, an inconsistent correlation between MRL and TRG was obtained in different stress concentration. A quite high coefficient of correlation $(r=0.72)$ was obtained when the plants were subjected iron stress in $100 \mathrm{ppm}$ $\mathrm{FeSO}_{4} .7 \mathrm{H} 2 \mathrm{O}$. On the contrary, the correlation was low ( $\mathrm{r}=$ 0.33 ) in the higher iron concentration of $200 \mathrm{ppm}$ of $\mathrm{FeSO}_{4} .7 \mathrm{H} 2 \mathrm{O}$. A low correlation between the longest and the total root growth $(\mathrm{r} 2=0.172)$ was also observed in the previous study for aluminum tolerance phenotyping in cereals (Famoso et al. 2010).

More genotypes were classified as tolerant using the RTI value of TRG parameter compared to MRL, either in $100 \mathrm{ppm}$ or $200 \mathrm{ppm}$ of $\mathrm{FeSO}_{4} .7 \mathrm{H} 2 \mathrm{O}$ (Table 4). This seems to be related to the number of seminal roots, since the TRG is measured by the sum of lengths of all seminal roots in the root system of rice seedlings. Almost all of the rice genotypes had more root number in the iron stress treatment as compared to the control (Figure 2). Iron stress might induce the seminal root growth as a defense mechanism in dealing with the stress. Therefore, all of the tolerant genotypes according to the TRG parameter produced considerably higher number of seminal roots than the sensitive genotypes under iron stressed condition (Figure 2). The sensitive genotypes "Bogor" and "Ketan Putek Iting" based on the RTI of TRG produced lower number of seminal roots in iron stressed condition as compared to that in the normal growth condition (Figure 2), thus had an extremely low total root growth (Table 1), and greatly total root growth reduction (Figure 1B). In contrast to those two genotypes, "Serai Gunung" which was sensitive based on the MRL was grouped as tolerant based on the TRG parameter (Table 2, Table 3). This genotype produced more root number in the iron stress treatment with an average root number 1.67, 2.00 and 3.00 in 0 ppm, $100 \mathrm{ppm}$ and $200 \mathrm{ppm} \mathrm{FeSO}_{4} .7 \mathrm{H} 2 \mathrm{O}$, respectively. Therefore the total root growth was higher (Table 1, Figure 1B), even though the plant had short maximal root length (Table 1, Figure 1A). The control of sensitive genotypes "IR64" remained sensitive based on the TRG value, since this genotype has not tolerance mechanisms against iron stress condition, the plant failed to form or extend the seminal roots under stress conditions.

Table 2. The iron tolerance level of the rice genotypes at different iron stress concentration based on the RTI value of the MRL

\begin{tabular}{llllll}
\hline \multirow{2}{*}{ Id } & \multirow{2}{*}{ Genotype } & \multicolumn{2}{c}{$\begin{array}{l}\text { 100 } \\
\text { FeSO }\end{array}$} & \multicolumn{2}{c}{$\begin{array}{c}\text { 200 } \\
\text { ppm }\end{array}$} \\
\cline { 3 - 6 } & & RTI & Category & RTI & Category \\
\hline V1 & IR 64 & 0.69 & Sensitive & 0.61 & Sensitive \\
V2 & Mekongga & 0.74 & Moderate & 0.71 & Moderate \\
V3 & Jala Mengo & 0.78 & Moderate & 0.76 & Moderate \\
V4 & Mayas & 0.88 & Moderate & 0.78 & Moderate \\
V5 & Kawit & 0.82 & Moderate & 0.80 & Moderate \\
V6 & Awang & 0.99 & Tolerant & 1.10 & Tolerant \\
V7 & Bentian & 0.92 & Tolerant & 0.91 & Tolerant \\
V8 & Ritam & 0.75 & Moderate & 0.74 & Moderate \\
V9 & Bogor Hitam & 1.24 & Tolerant & 1.33 & Tolerant \\
V10 & Bogor Putih & 1.15 & Tolerant & 0.84 & Moderate \\
V11 & Sungkai & 0.83 & Moderate & 0.79 & Moderate \\
V12 & Tumiyang & 0.72 & Moderate & 0.71 & Moderate \\
V13 & Melak & 0.89 & Moderate & 0.77 & Moderate \\
V14 & Bogor & 0.96 & Tolerant & 0.81 & Moderate \\
V15 & Mayas Kuning & 0.80 & Moderate & 0.68 & Sensitive \\
V16 & Mayas Putih & 0.92 & Tolerant & 0.73 & Moderate \\
V17 & Buyung & 1.14 & Tolerant & 1.11 & Tolerant \\
V18 & Serai Gunung & 0.74 & Moderate & 0.64 & Sensitive \\
V19 & Ketalun Tawar & 1.25 & Tolerant & 1.00 & Tolerant \\
V20 & Ketan Putih & 0.81 & Moderate & 0.81 & Moderate \\
V21 & Ketan Huan & 0.87 & Moderate & 0.74 & Moderate \\
V22 & Ketan Lekatan & 0.88 & Moderate & 0.86 & Moderate \\
V23 & Ketan Putek Iting & 0.74 & Moderate & 0.89 & Moderate \\
V24 & Ketan Mayang & 0.83 & Moderate & 0.83 & Moderate \\
V25 & Ketan Linjuang & 0.86 & Moderate & 0.86 & Moderate \\
\hline
\end{tabular}


Table 3. Iron tolerance level of the rice genotypes at different iron stress concentration based on the RTI value of the TRG

\begin{tabular}{llllll}
\hline \multirow{2}{*}{ Id } & \multirow{2}{*}{ Genotype } & \multicolumn{2}{c}{$\begin{array}{c}\text { 100 ppm } \\
\text { FeSO4.7H2O }\end{array}$} & \multicolumn{2}{c}{ Fo0 po4.7H2O } \\
\cline { 3 - 6 } & & RTI & Category & RTI & Category \\
\hline V1 & IR 64 & 0.62 & Sensitive & 0.61 & Sensitive \\
V2 & Mekongga & 1.00 & Tolerant & 0.98 & Tolerant \\
V3 & Jala Mengo & 0.73 & Moderate & 0.73 & Moderate \\
V4 & Mayas & 1.16 & Tolerant & 1.22 & Tolerant \\
V5 & Kawit & 0.86 & Moderate & 0.71 & Moderate \\
V6 & Awang & 0.84 & Moderate & 0.73 & Moderate \\
V7 & Bentian & 1.25 & Tolerant & 1.06 & Tolerant \\
V8 & Ritam & 0.84 & Moderate & 0.88 & Moderate \\
V9 & Bogor Hitam & 1.37 & Tolerant & 1.24 & Tolerant \\
V10 & Bogor Putih & 1.10 & Tolerant & 1.10 & Tolerant \\
V11 & Sungkai & 0.94 & Tolerant & 1.42 & Tolerant \\
V12 & Tumiyang & 0.75 & Moderate & 0.74 & Moderate \\
V13 & Melak & 0.93 & Tolerant & 0.89 & Moderate \\
V14 & Bogor & 0.77 & Moderate & 0.68 & Sensitive \\
V15 & Mayas Kuning & 1.01 & Tolerant & 0.82 & Moderate \\
V16 & Mayas Putih & 1.25 & Tolerant & 0.83 & Moderate \\
V17 & Buyung & 1.20 & Tolerant & 1.06 & Tolerant \\
V18 & Serai Gunung & 0.94 & Tolerant & 1.02 & Tolerant \\
V19 & Ketalun Tawar & 1.35 & Tolerant & 1.41 & Tolerant \\
V20 & Ketan Putih & 1.09 & Tolerant & 0.98 & Tolerant \\
V21 & Ketan Huan & 0.96 & Tolerant & 1.16 & Tolerant \\
V22 & Ketan Lekatan & 0.90 & Tolerant & 0.82 & Moderate \\
V23 & Ketan Putek Iting & 0.76 & Moderate & 0.66 & Sensitive \\
V24 & Ketan Mayang & 0.85 & Moderate & 0.84 & Moderate \\
V25 & Ketan Linjuang & 0.89 & Moderate & 0.84 & Moderate \\
\hline
\end{tabular}

Table 4. The tolerant genotypes based on the total root growth and maximal root length at different iron concentration.

\begin{tabular}{lllcc}
\hline Id. & \multicolumn{2}{c}{$\begin{array}{c}\text { Total Root Growth } \\
\text { (TRG) }\end{array}$} & \multicolumn{2}{c}{$\begin{array}{c}\text { Maximal root length } \\
\text { (MRL) }\end{array}$} \\
\cline { 2 - 5 } & \multicolumn{1}{c}{$\mathbf{1 0 0}$ ppm } & 200 ppm & $\mathbf{1 0 0}$ ppm & $\mathbf{2 0 0}$ ppm \\
\hline V2 Mekongga & Mekongga & - & - \\
V4 Mayas & Mayas & - & - \\
V6 & - & - & Awang & Awang \\
V7 Bentian & Bentian & Bentian & Bentian \\
V9 Bogor Hitam & Bogor Hitam & Bogor Hitam & Bogor Hitam \\
V10 Bogor Putih & Bogor Putih & Bogor Putih & - \\
V11 Sungkai & Sungkai & - & - \\
V13 Melak & - & - & - \\
V14 & - & - & Bogor & - \\
V15 Mayas Kuning & - & - & - \\
V16 Mayas Putih & - & Mayas Putih & - \\
V17 Buyung & - & Buyung & Buyung \\
V18 Serai Gunung & - & - & - \\
V19 Ketalun Tawar & - & - & - \\
V20 Ketan Putih & Ketan Putih & - & - \\
V21 Ketan Huan & Ketan Huan & - & - \\
V22 Ketan Lekatan & - & - & - \\
\hline
\end{tabular}

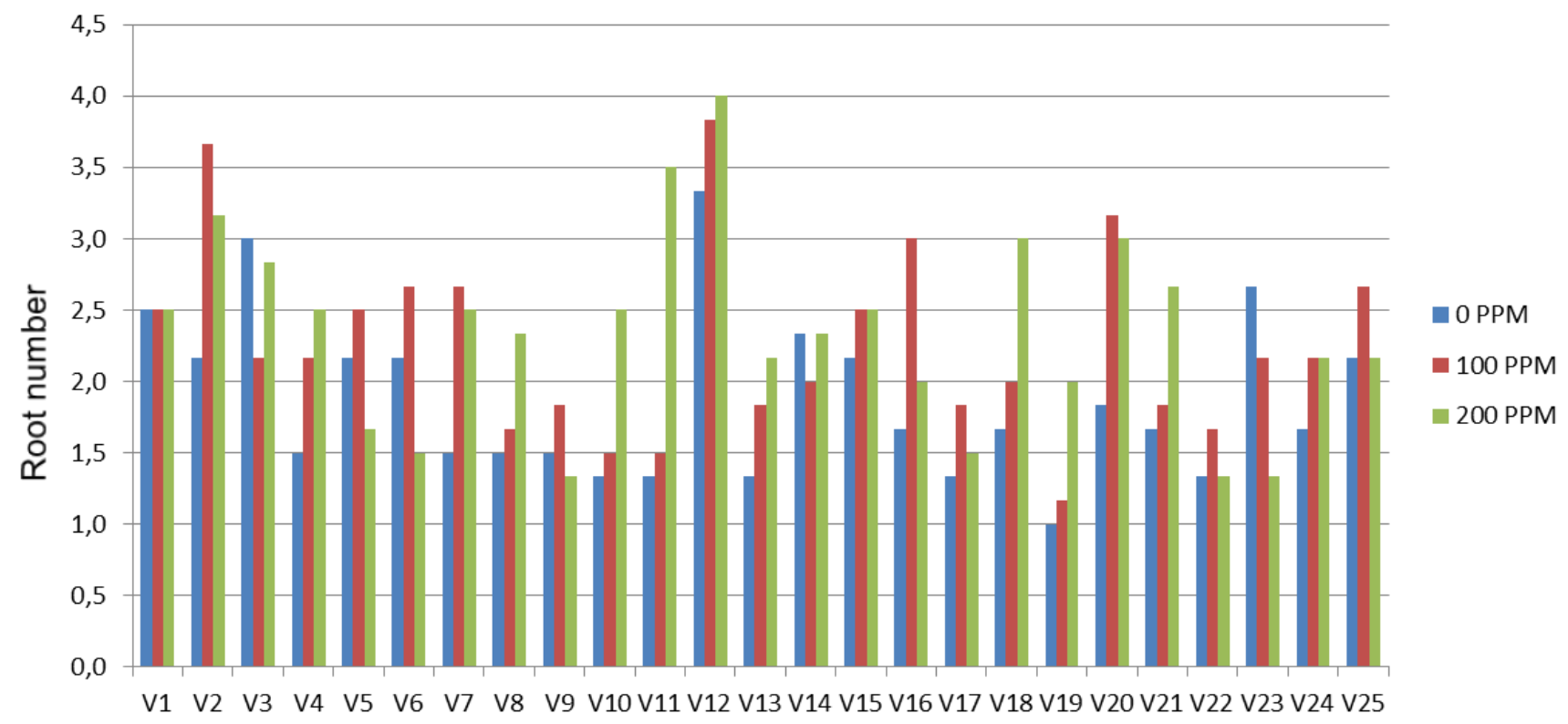

Rice genotypes

Figure 2. Root number of the rice genotypes at different iron stress concentration. V1 (IR 64), V2 (Mekongga), V3 (Jala Mengo), V4 (Mayas), V5 (Kawit), V6 (Awang), V7 (Bentian), V8 (Ritam), V9 (Bogor Hitam), V10 (Bogor Putih), V11 (Sungkai), V12 (Tumiyang), V13 (Melak), V14 (Bogor), V15 (Mayas Kuning), V16 (Mayas Putih), V17 (Buyung), V18 (Serai Gunung), V19 (Ketalun Tawar), V20 (Ketan Putih), V21 (Ketan Huan), V22 (Ketan Lekatan), V23 (Ketan Putek Iting), V24 (Ketan Mayang), V25 (Ketan Linjuang). 


\section{Shoot growth analysis}

The shoot growth of the rice genotypes varied, showing the genetic diversity of the rice genotypes. In normal growth condition, the shoot length of Ketan Huan cultivar was observed as the shortest and Ritam cultivar was the highest among all rice genotypes (Table 5). In iron stress condition, the shoot length of the local rice genotypes was reduced for most of genotypes. However, in particular genotypes the shoot length was increased in the stress situation as observed in Ketan Huan, Sungkai, and Bentian cultivars (Table 5). The shoot length reduction percentage was in line with the iron stress concentration. The higher iron stress concentration, the higher the shoot length reduction (Figure 3). The highest shoot length reduction was $-24.83 \%$ and $-36.65 \%$ in $100 \mathrm{ppm}$ and $200 \mathrm{ppm}$ of $\mathrm{FeSO}_{4} .7 \mathrm{H} 2 \mathrm{O}$, respectively. Nevertheless, the reduction percentage was considered lower than that of the root growth (Figure 1). The shoot growth seems to be less affected by iron poisoning condition compared to the root growth.

Several studies reported the association between iron toxicity and plant height reduction (Asch et al. 2005; Majerus et al. 2007, Fageria et al. 2008). The stunted shoot growth is resulted from the mineral and nutrient deficiency (Rout et al 2014) due to the 'iron plaque' coated the root surface (Sahrawat 2004; Chen et al. 2006; Elec et al. 2013) disrupting their absorption by the plant. This condition will cause multiple nutritional disorders interfering plant metabolism processes (Rout and Sahoo, 2015) and further affected plant growth (Dorlodot et al. 2005; Majerus et al. 2007), or death of the plant (Chérif et al., 2009). In this case, the shoot growth disruption can be stated as the secondary effect from the iron toxicity inhibiting the root growth. Therefore, the shoot growth disorders were not as severe as the root growth disturbance due to iron poisoning.

If we calculate the tolerance index (TI) based on the shoot growth, in this study we used shoot length, the tolerance index will range from 0.75 to 1.24 and from 0.63 to 1.33 in $100 \mathrm{ppm}$ and $200 \mathrm{ppm} \mathrm{FeSO} 4.7 \mathrm{H} 2 \mathrm{O}$, respectively (Table 6); in which none of the genotypes was sensitive except for IR64 variety at the $200 \mathrm{ppm}$ of $\mathrm{FeSO}_{4} .7 \mathrm{H} 2 \mathrm{O}$. Based on this, twenty from twenty-three of the local rice genotypes were grouped as tolerant in $100 \mathrm{ppm}$, and fifteen of them remain tolerant in the higher iron toxicity concentration. It means that the iron concentration of 100 ppm of $\mathrm{FeSO}_{4} .7 \mathrm{H} 2 \mathrm{O}$ was not high enough for selecting the sensitive genotype based on the shoot length; a higher iron poisoning concentration is needed. Other morphological symptoms of iron toxicity on the leaf such as the presence of purplish-brown spots followed by leaves drying or leaf bronzing (Yamauchi dan Peng 1993; Becker and Asch 2005) were not present in this study. A higher iron concentration or longer stress duration might be needed for observing such condition in rice seedlings of the genotypes used in this study. The leaf-bronzing symptom on affected plant depends on the intensity and the duration of the $\mathrm{Fe}$ stress and genotype-specific tolerance mechanisms (Becker and Asch 2005). In other studies, growth reduction might present without significant leaf bronzing (Onaga et al. 2012; Sikirou et al 2016). There is also no clear information between $\mathrm{Fe}$ concentrations in the plant with the leaf symptoms (Elec et al. 2013).

\section{Plant biomass analysis}

Iron stress condition influences biomass accumulation on the plants (Sahrawat 2004; Quinnet et al., 2012). However, according to Sikirou et al. (2015), shoot length and plant biomass were included as secondary traits for abiotic stress tolerance indirect selection. In this study, iron stress treatment also resulted in the reduction of fresh and dry biomass of the plants (Table 7) for most of the rice genotypes. The level of biomass reduction varied depending on the rice genotypes (Figure 4). Several genotypes showed a reduction of biomass especially in 200 ppm of $\mathrm{FeSO}_{4} .7 \mathrm{H} 2 \mathrm{O}$ as observed in the sensitive control IR64, in which the plant biomass remarkably reduced up to more than $50 \%$. Whereas other genotypes had a higher biomass accumulation in the iron stress condition, as observed in Bogor, Sungkai, Tumiyang, and Melak cultivars. Those genotypes were grouped as tolerant and moderately tolerant genotype based on the root tolerance analysis. The fresh weight tended to be more interfered by the iron toxic condition compared to the dry weight (Figure 4).

Table 5. Shoot length of the rice genotypes at a different FeSO4.7H2O concentration

\begin{tabular}{lllccc}
\hline & & & \multicolumn{3}{c}{ Shoot Length $(\mathbf{c m})$} \\
\cline { 3 - 6 } Id & Genotype & Rice type & 0 ppm & $\mathbf{1 0 0}$ & $\mathbf{2 0 0}$ \\
& & & ppm & ppm \\
\hline V1 & IR 64 & Non-glutinous & 13.05 & 11.40 & 8.27 \\
V2 & Mekongga & Non-glutinous & 16.17 & 14.57 & 14.30 \\
V3 & Jala Mengo & Non-glutinous & 15.68 & 15.85 & 15.02 \\
V4 & Mayas & Non-glutinous & 13.17 & 15.80 & 12.47 \\
V5 & Kawit & Non-glutinous & 16.02 & 14.72 & 14.67 \\
V6 & Awang & Non-glutinous & 16.67 & 16.12 & 15.83 \\
V7 & Bentian & Non-glutinous & 17.17 & 17.40 & 20.63 \\
V8 & Ritam & Non-glutinous & 19.95 & 15.70 & 15.62 \\
V9 & Bogor Hitam & Non-glutinous & 17.92 & 17.67 & 16.20 \\
V10 & Bogor Putih & Non-glutinous & 18.23 & 17.93 & 17.67 \\
V11 & Sungkai & Non-glutinous & 11.05 & 12.37 & 11.22 \\
V12 & Tumiyang & Non-glutinous & 16.15 & 18.08 & 15.88 \\
V13 & Melak & Non-glutinous & 17.97 & 18.02 & 17.97 \\
V14 & Bogor & Non-glutinous & 13.22 & 12.93 & 12.57 \\
V15 & Mayas Kuning & Non-glutinous & 14.00 & 12.92 & 12.70 \\
V16 & Mayas Putih & Non-glutinous & 16.82 & 15.82 & 13.65 \\
V17 & Buyung & Non-glutinous & 14.97 & 11.25 & 12.72 \\
V18 & Serai Gunung & Non-glutinous & 13.87 & 14.93 & 13.50 \\
V19 & Ketalun Tawar & Non-glutinous & 12.83 & 11.77 & 13.05 \\
V20 & Ketan Putih & Glutinous & 16.65 & 14.22 & 14.88 \\
V21 & Ketan Huan & Glutinous & 9.87 & 9.95 & 13.12 \\
V22 & Ketan Lekatan & Glutinous & 16.95 & 21.05 & 18.07 \\
V23 & Ketan Putek Iting & Glutinous & 15.88 & 15.95 & 12.82 \\
V24 & Pulut Mayang & Glutinous & 13.12 & 13.52 & 11.78 \\
V25 & Pulut Linjuang & Glutinous & 13.47 & 12.70 & 11.58 \\
\hline & & & & &
\end{tabular}




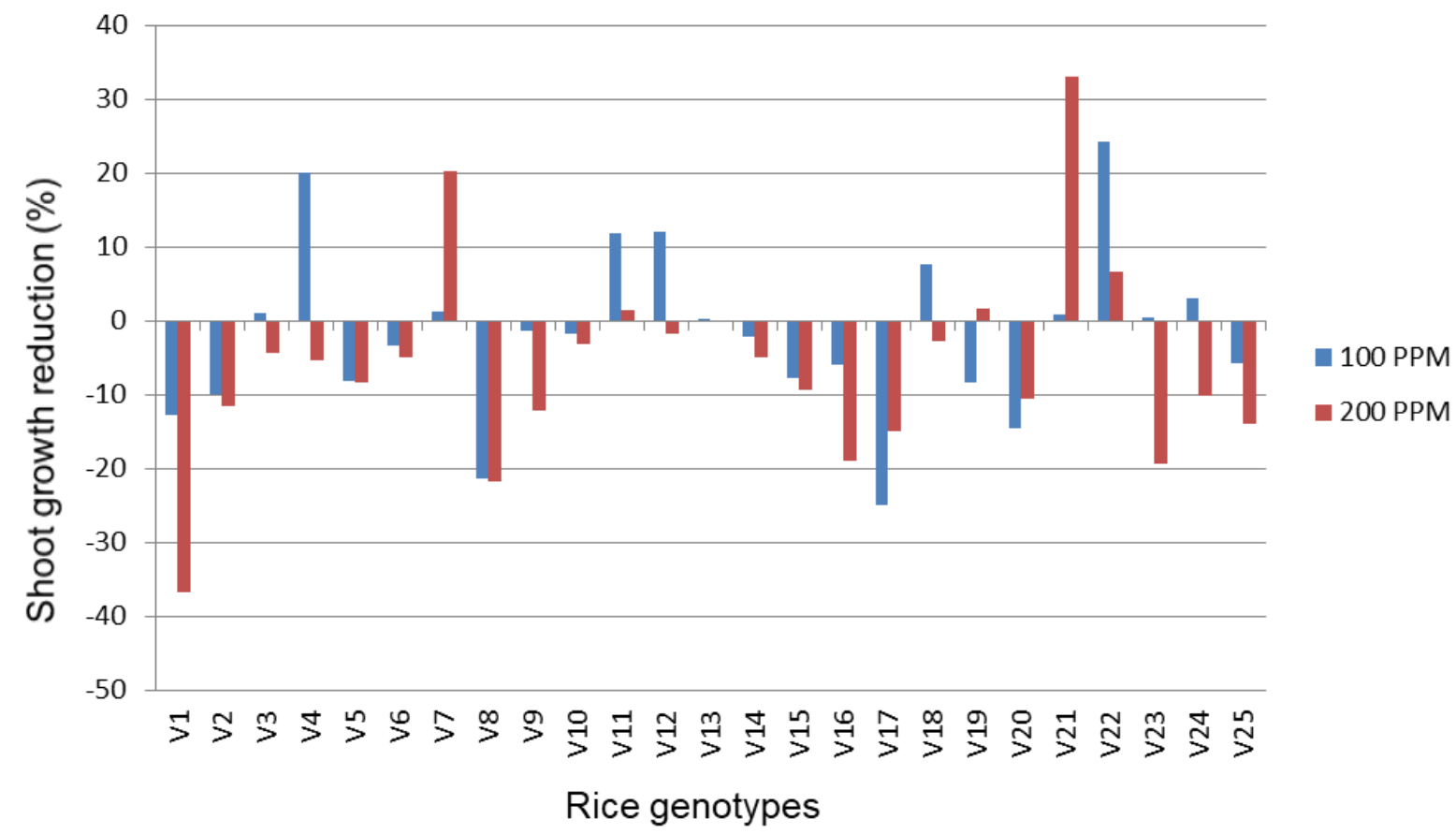

Figure 3. Percentage of the shoot growth reduction or accretion of the rice genotypes at different iron stress concentration. V1 (IR 64), V2 (Mekongga), V3 (Jala Mengo), V4 (Mayas), V5 (Kawit), V6 (Awang), V7 (Bentian), V8 (Ritam), V9 (Bogor Hitam), V10 (Bogor Putih), V11 (Sungkai), V12 (Tumiyang), V13 (Melak), V14 (Bogor), V15 (Mayas Kuning), V16 (Mayas Putih), V17 (Buyung), V18 (Serai Gunung), V19 (Ketalun Tawar), V20 (Ketan Putih), V21 (Ketan Huan), V22 (Ketan Lekatan), V23 (Ketan Putek Iting), V24 (Ketan Mayang), V25 (Ketan Linjuang).

Table 6. The tolerance level of the rice genotypes at different iron stress concentration based on the shoot length (SL)

\begin{tabular}{lllcll}
\hline \multirow{2}{*}{ Id } & Genotype & \multicolumn{2}{c}{$\begin{array}{c}\text { 100 ppm } \\
\text { FeSO4.7H2O }\end{array}$} & \multicolumn{2}{c}{ Fo0 ppm } \\
& & TI & Category & TI & Category \\
\cline { 2 - 6 } V1 & IR 64 & 0.87 & Moderate & 0.63 & Sensitive \\
V2 & Mekongga & 0.90 & Tolerant & 0.88 & Moderate \\
V3 & Jala Mengo & 1.01 & Tolerant & 0.96 & Tolerant \\
V4 & Mayas & 1.20 & Tolerant & 0.95 & Tolerant \\
V5 & Kawit & 0.92 & Tolerant & 0.92 & Tolerant \\
V6 & Awang & 0.97 & Tolerant & 0.95 & Tolerant \\
V7 & Bentian & 1.01 & Tolerant & 1.20 & Tolerant \\
V8 & Ritam & 0.79 & Moderate & 0.78 & Moderate \\
V9 & Bogor Hitam & 0.99 & Tolerant & 0.90 & Tolerant \\
V10 & Bogor Putih & 0.98 & Tolerant & 0.97 & Tolerant \\
V11 & Sungkai & 1.12 & Tolerant & 1.02 & Tolerant \\
V12 & Tumiyang & 1.12 & Tolerant & 0.98 & Tolerant \\
V13 & Melak & 1.00 & Tolerant & 1.00 & Tolerant \\
V14 & Bogor & 0.98 & Tolerant & 0.95 & Tolerant \\
V15 & Mayas Kuning & 0.92 & Tolerant & 0.91 & Tolerant \\
V16 & Mayas Putih & 0.94 & Tolerant & 0.81 & Moderate \\
V17 & Buyung & 0.75 & Moderate & 0.85 & Moderate \\
V18 & Serai Gunung & 1.08 & Tolerant & 0.97 & Tolerant \\
V19 & Ketalun Tawar & 0.92 & Tolerant & 1.02 & Tolerant \\
V20 & Ketan Putih & 0.85 & Moderate & 0.89 & Moderate \\
V21 & Ketan Huan & 1.01 & Tolerant & 1.33 & Tolerant \\
V22 & Ketan Lekatan & 1.24 & Tolerant & 1.07 & Tolerant \\
V23 & Ketan Putek Iting & 1.00 & Tolerant & 0.81 & Moderate \\
V24 & Pulut Mayang & 1.03 & Tolerant & 0.90 & Tolerant \\
V25 & Pulut Linjuang & 0.94 & Tolerant & 0.86 & Moderate \\
\hline & & & & &
\end{tabular}

The tolerance index (TI) of fresh biomass showed the inconsistent result, in which two local rice genotypes, Ketan Putih and Ketan Huan which were sensitive in 100 ppm became tolerant in the higher iron concentration of $200 \mathrm{ppm}$ (Table 8). On the other hand, in dry biomass character, almost all of the rice genotypes were tolerant to the iron stress treatment (Table 9). It was suspected that these characters were less sensitive to screen the tolerance level of the plants against iron stress, as observed in the shoot length character. The reason might be because the shoot growth and biomass accumulation are the secondary effects resulted from the root growth disorder (Sahrawat et al 2004; Dorlodot et al. 2005). Therefore a higher or longer term of iron poisoning treatment should be done to use these characters as selection criteria in evaluating plant response against the stress (Mehraban et al. 2008; Rout et al 2014).

In conclusion, iron concentration of 100 and $200 \mathrm{ppm}$ of $\mathrm{FeSO}_{4} .7 \mathrm{H} 2 \mathrm{O}$ inhibited the growth of root, shoot, and biomass of rice seedling. The effect was increasing in line with the increase of iron concentration. The response of each East Kalimantan local rice genotypes varied in facing iron stress condition, showing a different level of tolerance. Shoot length and plant biomass were less disturbed by the iron toxicity treatment of 100 and 200 ppm of FeSO $4.7 \mathrm{H} 2 \mathrm{O}$ for a week. Among growth parameters, MRL and TRG can be used for early screening of the tolerant genotypes in the seedling stage. The tolerance index values of the TRG selected more genotypes which were tolerant compared to 
the MRL. The iron stress condition might induce the seminal root growth as a defense mechanism in tolerant genotypes thus increasing the total root number and total root growth. However, the most selective character for iron toxicity screening causing more severe symptoms for most of the genotypes was MRL character, compared to the total root growth. Most all of the tolerant genotypes based on the tolerance index of the MRL were also tolerant based on the TRG. Two local rice genotypes, Bentian and Bogor Hitam, were consistently tolerant based on the maximal root growth, total root growth, shoot length, and plant biomass.

Table 7. Mean value of fresh and dry biomass of the rice genotypes at different iron stress concentration

\begin{tabular}{|c|c|c|c|c|c|c|c|c|}
\hline \multirow{2}{*}{ Id } & \multirow{2}{*}{ Genotype } & \multirow{2}{*}{ Rice type } & \multicolumn{3}{|c|}{ Fresh biomass (g) } & \multicolumn{3}{|c|}{ Dry biomass (g) } \\
\hline & & & 0 ppm & 100 ppm & 200 ppm & 0 ppm & 100 ppm & 200 ppm \\
\hline V1 & IR 64 & Non-glutinous & 0.0523 & 0.0352 & 0.0234 & 0.0097 & 0.0085 & 0.0047 \\
\hline V2 & Mekongga & Non-glutinous & 0.0762 & 0.0678 & 0.0703 & 0.0121 & 0.0114 & 0.0111 \\
\hline V3 & Jala Mengo & Non-glutinous & 0.0786 & 0.0773 & 0.0795 & 0.0133 & 0.0144 & 0.0143 \\
\hline V4 & Mayas & Non-glutinous & 0.0364 & 0.0371 & 0.0379 & 0.0066 & 0.0086 & 0.0093 \\
\hline V5 & Kawit & Non-glutinous & 0.0521 & 0.0488 & 0.0458 & 0.0083 & 0.0081 & 0.0076 \\
\hline V6 & Awang & Non-glutinous & 0.0719 & 0.0765 & 0.0787 & 0.0114 & 0.0110 & 0.0124 \\
\hline V7 & Bentian & Non-glutinous & 0.0598 & 0.0663 & 0.0790 & 0.0103 & 0.0123 & 0.0124 \\
\hline V8 & Ritam & Non-glutinous & 0.0620 & 0.0483 & 0.0540 & 0.0096 & 0.0097 & 0.0087 \\
\hline V9 & Bogor Hitam & Non-glutinous & 0.0536 & 0.0692 & 0.0528 & 0.0083 & 0.0120 & 0.0093 \\
\hline V10 & Bogor Putih & Non-glutinous & 0.0532 & 0.0722 & 0.0633 & 0.0098 & 0.0119 & 0.0115 \\
\hline V11 & Sungkai & Non-glutinous & 0.0448 & 0.0543 & 0.0510 & 0.0074 & 0.0096 & 0.0090 \\
\hline V12 & Tumiyang & Non-glutinous & 0.0767 & 0.1062 & 0.0819 & 0.0106 & 0.0160 & 0.0145 \\
\hline V13 & Melak & Non-glutinous & 0.0601 & 0.0619 & 0.0705 & 0.0101 & 0.0109 & 0.0133 \\
\hline V14 & Bogor & Non-glutinous & 0.0603 & 0.0538 & 0.0500 & 0.0091 & 0.0098 & 0.0096 \\
\hline V15 & Mayas Kuning & Non-glutinous & 0.0425 & 0.0451 & 0.0410 & 0.0080 & 0.0096 & 0.0090 \\
\hline V16 & Mayas Putih & Non-glutinous & 0.0572 & 0.0663 & 0.0505 & 0.0084 & 0.0113 & 0.0092 \\
\hline V17 & Buyung & Non-glutinous & 0.0527 & 0.0480 & 0.0523 & 0.0077 & 0.0073 & 0.0092 \\
\hline V18 & Serai Gunung & Non-glutinous & 0.0625 & 0.0626 & 0.0488 & 0.0090 & 0.0092 & 0.0082 \\
\hline V19 & Ketalun Tawar & Non-glutinous & 0.0405 & 0.0426 & 0.0526 & 0.0070 & 0.0071 & 0.0091 \\
\hline V20 & Ketan Putih & Glutinous & 0.0822 & 0.0565 & 0.0799 & 0.0109 & 0.0101 & 0.0117 \\
\hline V21 & Ketan Huan & Glutinous & 0.0404 & 0.0280 & 0.0455 & 0.0056 & 0.0043 & 0.0089 \\
\hline V22 & Ketan Lekatan & Glutinous & 0.0615 & 0.0895 & 0.0905 & 0.0145 & 0.0148 & 0.0145 \\
\hline V23 & Ketan Putek Iting & Glutinous & 0.0637 & 0.0700 & 0.0590 & 0.0101 & 0.0109 & 0.0098 \\
\hline V24 & Ketan Mayang & Glutinous & 0.0677 & 0.0710 & 0.0933 & 0.0110 & 0.0118 & 0.0121 \\
\hline $\mathrm{V} 25$ & Ketan Linjuang & Glutinous & 0.0935 & 0.0847 & 0.0604 & 0.0146 & 0.0140 & 0.0122 \\
\hline
\end{tabular}
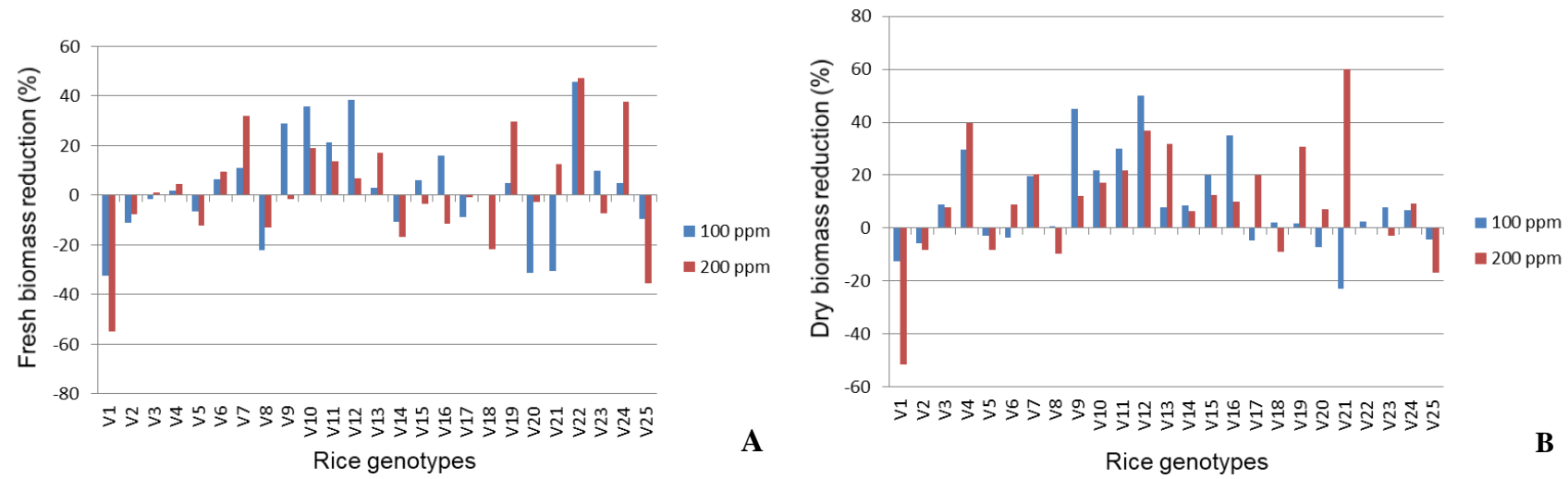

Figure 4. Percentage of the biomass growth reduction or accretion of the rice genotypes at different iron stress concentration. A. Fresh biomass; B. Dry biomass. V1 (IR 64), V2 (Mekongga), V3 (Jala Mengo), V4 (Mayas), V5 (Kawit), V6 (Awang), V7 (Bentian), V8 (Ritam), V9 (Bogor Hitam), V10 (Bogor Putih), V11 (Sungkai), V12 (Tumiyang), V13 (Melak), V14 (Bogor), V15 (Mayas Kuning), V16 (Mayas Putih), V17 (Buyung), V18 (Serai Gunung), V19 (Ketalun Tawar), V20 (Ketan Putih), V21 (Ketan Huan), V22 (Ketan Lekatan), V23 (Ketan Putek Iting), V24 (Ketan Mayang), V25 (Ketan Linjuang). 
Table 8. The tolerance level of the rice genotypes at different iron stress concentration based on the total fresh biomass character

\begin{tabular}{clclcl}
\hline \multirow{2}{*}{ Id } & \multirow{2}{*}{ Genotype } & \multicolumn{2}{c}{$\begin{array}{c}\text { 100 ppm } \\
\text { FeSO4.7H2O }\end{array}$} & \multicolumn{2}{c}{$\begin{array}{c}\text { 200 ppm } \\
\text { FeSO.7H2O }\end{array}$} \\
\cline { 3 - 6 } & & TI & Category & TI & Category \\
\hline V1 & IR 64 & 0.6730 & Sensitive & 0.4481 & Sensitive \\
V2 & Mekongga & 0.8893 & Moderate & 0.9222 & Tolerant \\
V3 & Jala Mengo & 0.9843 & Tolerant & 1.0115 & Tolerant \\
V4 & Mayas & 1.0192 & Tolerant & 1.0431 & Tolerant \\
V5 & Kawit & 0.9361 & Tolerant & 0.8779 & Moderate \\
V6 & Awang & 1.0640 & Tolerant & 1.0950 & Tolerant \\
V7 & Bentian & 1.1093 & Tolerant & 1.3211 & Tolerant \\
V8 & Ritam & 0.7785 & Moderate & 0.8704 & Moderate \\
V9 & Bogor Hitam & 1.2909 & Tolerant & 0.9838 & Tolerant \\
V10 & Bogor Putih & 1.3578 & Tolerant & 1.1898 & Tolerant \\
V11 & Sungkai & 1.2113 & Tolerant & 1.1384 & Tolerant \\
V12 & Tumiyang & 1.3844 & Tolerant & 1.0673 & Tolerant \\
V13 & Melak & 1.0288 & Tolerant & 1.1724 & Tolerant \\
V14 & Bogor & 0.8927 & Moderate & 0.8294 & Moderate \\
V15 & Mayas Kuning & 1.0612 & Tolerant & 0.9647 & Tolerant \\
V16 & Mayas Putih & 1.1592 & Tolerant & 0.8828 & Moderate \\
V17 & Buyung & 0.9108 & Tolerant & 0.9924 & Tolerant \\
V18 & Serai Gunung & 1.0016 & Tolerant & 0.7802 & Tolerant \\
V19 & Ketalun Tawar & 1.0502 & Tolerant & 1.2985 & Tolerant \\
V20 & Ketan Putih & 0.6873 & Sensitive & 0.9724 & Tolerant \\
V21 & Ketan Huan & 0.6922 & Sensitive & 1.1262 & Tolerant \\
V22 & Ketan Lekatan & 1.4553 & Tolerant & 1.4721 & Tolerant \\
V23 & Ketan Putek Iting & 1.0995 & Tolerant & 0.9267 & Tolerant \\
V24 & Pulut Mayang & 1.0492 & Tolerant & 1.3781 & Tolerant \\
V25 & Pulut Linjuang & 0.9055 & Tolerant & 0.6460 & Sensitive \\
\hline & & & & & \\
\hline
\end{tabular}

Table 9. The tolerance level of the rice genotypes at different iron stress concentration based on the total dry biomass character

\begin{tabular}{|c|c|c|c|c|c|}
\hline \multirow[t]{2}{*}{ Id } & \multirow[t]{2}{*}{ Genotype } & \multicolumn{2}{|c|}{$\begin{array}{c}100 \text { ppm } \\
\text { FeSO4.7H2O } \\
\end{array}$} & \multicolumn{2}{|c|}{$\begin{array}{c}200 \text { ppm } \\
\text { FeSO4.7H2O } \\
\end{array}$} \\
\hline & & TI & Category & TI & Categor \\
\hline V1 & IR 64 & .8733 & Modes & 0.4863 & ive \\
\hline V2 & Mekongga & 9423 & & 9176 & \\
\hline V3 & Jala M & 0879 & & 0779 & \\
\hline V4 & Mayas & 2965 & To & 3970 & \\
\hline V5 & Kaw & 0.9720 & & & \\
\hline V6 & $\mathrm{Aw}$ & & & & \\
\hline V7 & Ben & 48 & & 45 & \\
\hline V8 & Rita & 59 & & 9028 & \\
\hline V9 & Bog & 4516 & & 1210 & \\
\hline V10 & & 177 & & 1701 & \\
\hline V11 & & 2986 & & 2172 & \\
\hline V12 & & 016 & & 3668 & \\
\hline V13 & & 792 & & 3168 & \\
\hline V14 & $\mathrm{H}$ & 846 & & 625 & \\
\hline V15 & 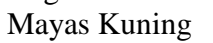 & 008 & & 255 & \\
\hline V16 & (av & 506 & & 96 & \\
\hline V17 & 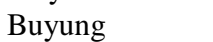 & 524 & & 1991 & $\mathrm{To}$ \\
\hline V18 & 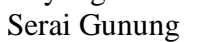 & 221 & & .9114 & Tolerant \\
\hline V19 & eta & 191 & & .3062 & Tolerant \\
\hline $\mathrm{V} 20$ & eta & 9268 & & .0701 & Tolerant \\
\hline $\mathrm{V} 21$ & Ketan Huan & 7725 & Moc & 1.5988 & Tolerant \\
\hline V22 & Ketan Lekat & .0230 & Toleı & 1.0000 & Tolerant \\
\hline V23 & the & 1.0792 & Toleı & 0.9703 & Tolerant \\
\hline V24 & Pulut Ma & 1.0665 & Tolerant & 1.0937 & Tolerant \\
\hline $\mathrm{V} 25$ & Pulut Linjuang & 0.9567 & Tolerant & 0.8314 & Moderate \\
\hline
\end{tabular}

\section{ACKNOWLEDGEMENTS}

This study was financed by Penelitian Terapan Unggulan Perguruan Tinggi (PTUPT) in Mulawarman University with contract number 372/UN17.41/KL/2017 Ministry of Research, Technology and Higher Education, to which the authors are highly indebted.

\section{REFERENCES}

Anjum NA, Singh HP, Khan MIR, Mason A, Per TS, Negi A, Batish DR, Khan NA, Duarte AC, Pereira E, Ahmad I. 2015. Too much is badan appraisal of phytotoxicity of elevated plant-beneficial heavy metal ions. Environ Sci Pollut Res 22: 3361-3382.

Asch, F, M Becker, DS Kpongor. 2005. A quick and efficient screen for tolerance to iron toxicity in lowland rice. J Plant Nutr Soil Sci 168: 764-773.

Audebert A, Fofana M. 2009. Rice yield gap due to iron toxicity in West Africa. J Agron Crop Sci 195 (1): 66-76.

Audebert A, Sahrawat KL. 2000. Mechanisms for iron toxicity tolerance in lowland rice. J Plant Nutr 23: 1877-1885.

Becker M, Asch F. 2005. Iron toxicity in rice-conditions and management concepts. Journal of Plant Nutrition and Soil Science - Zeitschrift Fur Pflanzenernahrung Und Bodenkunde 168: 558-573.

Briat JF, Fobis-Loisy I, Grignon N, Lobréaux S, Pascal N, Savino G, Thoiron S, von Wirn N, van Wuytswinkel O. 1995 Cellular and molecular aspects of iron metabolism in plants. Biol Cell 84: 69-81.

Chen RF, Shen RF, Gu P, Dong XY, Du CW, Ma JF. 2006. Response of Rice (Oryza sativa) with Root Surface Iron Plaque Under Aluminium Stress. Annals of Botany 98: 389-395.
Chérif M, Audebert A, Fofana M, Zouzou M. 2009. Evaluation of iron toxicity on lowland irrigated rice in West Africa. Tropicultura 27: 1970-1975

Connolly EL, Guerinot ML 2002 Iron stress in plants. Genome Biol 3 (8): $1-4$

Curie C, Briat JF. 2003. Iron transport and signaling in plants. Ann Rev Plant Biol 54: 183-206.

Dobermann A, Fairhurst TH. 2000. Nutrient Disorders and Nutrient Management. International Rice Research Institute, Los Banos, Philippines

Dorlodot S, Lutts S, Bertin P. 2005. Effect of ferrous iron toxicity on the growth and mineral competition of and interspecific rice. J Plant Nutr 28 (1): 1-20.

Emamverdian A, Ding Y, Mokhberdoran F, Xie Y. 2015. Heavy metal stress and some mechanisms of plant defense response. Sci World J DOI: $101155 / 2015 / 756120$.

Elec V, Quimio CA, Mendoza R, Sajise AG, Beebout SEJ, Gregorio GB, Singh RK 2013 Maintaining elevated Fe2+ concentration in solution culture for the development of a rapid and repeatable screening technique for iron toxicity tolerance in rice (Oryza sativa L). Plant Soil DOI: 101007/s11104-013-1739-4.

Fageria NK, Santos AB, Filho MPB, Guimaraes CM. 2008. Iron toxicity in lowland rice. J Plant Nutr 31: 1676-1697.

Famoso AN, Clark RT, Shaff JE, Craft E, McCouch SR, Kochian LV. 2010. Development of a novel aluminum tolerance phenotyping platform used for comparisons of cereal aluminum tolerance and investigations into rice aluminum tolerance mechanisms. Plant Physiol 153 (4): 1678-1691.

Jena D, Nayak SC, Dash AK, Mohanty B, Jena B. 2008. Effect of soil amendments on yield and iron content of rice in iron toxic soil. Asian J Soil Sci 3 (2): 264-268.

Kim SA, Guerinot ML. 2007. Mining iron: iron uptake and transport in plants. FEBS Lett 581: 2273-2280.

Lan P, Li W, Wen TN, Shiau JY, Wu YC, Lin W, Schmidt W. (2011) iTRAQ protein profile analysis of Arabidopsis roots reveals new aspects critical for iron homeostasis. Plant Physiol 155: 821-834. 
Majerus V, Bertin P, Lutts S. 2007. Effects of iron toxicity on osmotic potential, osmolytes and polyamines concentrations in the African rice (Oryza glaberrima Steud). Plant Sci 173: 96-105.

Mackill DJ, Khush GS. 2018 IR64: a high-quality and high-yielding mega variety. Rice 11 (18): 1-11.

Mehraban P, Zadeh AA, Sadeghipour HR. 2008 Iron toxicity in rice (Oryza sativa $\mathrm{L}$ ) under different potassium nutritiom. Asian J Plant Sci 1-9.

Morrissey J, Guerinot ML. 2009. Iron uptake and transport in plants: The good, the bad, and the ionome. Chem Rev 109 (10): 4553-4567.

Noor A, Lubis I, Ghulamahdi M, Chozin MA, Anwar K, Wirnas D. 2012. Effect of iron concentration in the nutrient solution to the symptoms of iron toxicity and growth of rice plants. J Agron Indonesia 40 (2) 91-98.

Nozoe T, Shinano T, Tachibana M, Uchino A. 2010. Tolerance of rice (Oryza sativa L) and echinochloa weeds to growth suppression by rice straw added to paddy soil in relation to iron toxicity. Plant Prod Sci 13 (3): 314-318.

Nugraha Y, Indrastuti AR, Guswara A, Aswidinnoor H. 2016. Responses of Selected Indonesian Rice Varieties under Excess Iron Condition in Media Culture at Seedling Stage. Penelitian Pertanian Tanaman Pangan 35 (3): 181-190.

Nurhasanah. 2007. Pemetaan Potensi Genetik Kultivar-Kultivar Padi Lokal Asal Kalimantan Timur untuk Sifat Kualitas Hasil dan Ketahanan Terhadap Cekaman Lingkungan Biotik dan Abiotik. Research Report. Mulawarman University, Samarinda. [Indonesian]

Nurhasanah, Sadaruddin, Sunaryo W. 2016. Diversity analysis and genetic potency identification of local rice cultivars in Penajam Paser Utara and Paser Districts East Kalimantan. Biodiversitas 17 (2): 401-408.

Nurhasanah, Sadaruddin, Sunaryo W. 2017. Yield-related traits characterization of local upland rice cultivars originated from East and North Kalimantan Indonesia. Biodiversitas 18 (3): 1165-1172

Nurhasanah, Mujiono K, Suryadarma E and Sunaryo, W. 2018. Genetic resistance of local upland rice populations from East and North Kalimantan, Indonesia against some important diseases. Austr J Crop Sci 12 (2): 326-334.

Onaga G, Edema R, Asea G. 2012. Tolerance of rice germplasm to iron toxicity stress and the relationship between tolerance, $\mathrm{Fe} 2+, \mathrm{P}$ and $\mathrm{K}$ content in the leaves and roots. Arch Agron Soil Sci 59: 213-229.

Quinet M, Vromman D, Clippe A, Bertin P, Lequeux H, Dufey I, Lutts S, Lefèvre I. 2012. Combined transcriptomic and physiological approaches reveal strong differences between short- and long-term response of rice (Oryza sativa) to iron toxicity. Plant Cell Environ 35 1837-1859.

Richard C, Munyinda K, Kinkese T, Osiru DS. 2015. Genotypic Variation in Seedling Tolerance to Aluminum Toxicity in Historical Maize Inbred Lines of Zambia. Agronomy 5: 200-219.
Rout GR, Sahoo S. 2015. Role of iron in plant growth and metabolism. Rev Agric Sci 3: 1-24.

Rout GR, Sahoo S, Das AB, Das SR. 2014. Screening of iron toxicity in rice genotypes on the basis of morphological, physiological and biochemical analysis. J Exp Biol Agric Sci 2 (6): 567-82

Sahrawat KL. 2004. Iron toxicity in wetland rice and the role of other nutrients. J Plant Nutr 27 (8): 1471-04

Sahrawat KL, Diatta S. 1995. Nutrient management and season affect soil iron toxicity. Annual Report 1994 West Africa Rice Development Association, Bouaké, Côte d'Ivoire.

Sahrawat KL, Diatta S, Singh BN. 2000. Reducing iron toxicity in lowland rice through an integrated use of tolerant genotypes and plant nutrient management. Oryza 37: 44-47.

Sari WM, Bayu ES, Ilyas S. 2013. Karakter vegetatif dan generatif beberapa varietas padi (Oryza sativa L.) toleran aluminum. Jurnal Online Agroekoteknologi 1 (4): 1424-1438.

Sikirou M, Saito K, Achigan-Dako EG, Dramé KN, Ahanchédé A, Venuprasad A. 2015. Genetic Improvement of Iron Toxicity Tolerance in Rice-Progress, Challenges and Prospects in West Africa. Plant Prod Sci 18 (4): 423-434.

Sikirou M, Saito K, Dramé KN, Saidou A, Dieng I, Ahanchédé A, Venuprasad R. 2016. Soil-based screening for iron toxicity tolerance in rice using pots, Plant Prod Sci 19 (4): 489-496.

Suprihatno B, Daradjat AA, Satoto, Baehaki SE, Widiarta IN, Setyono A, Indrasari SD, Lesmana OS, Sembiring H. 2009 Deskripsi varietas padi. Balai Besar Penelitian Tanaman Padi, Subang. [Indonesian]

Tripathi DK, Singh S, Singh S, Mishra S, Chauhan DK, Dubey NK. 2015. Micronutrients and their diverse role in agricultural crops: advances and future prospective. Acta Physiol Plantar 37: 1-14.

Tripathi DK, Singh S, Gaur S, Singh S, Yadav V, Liu S, Singh VP, Sharma S, Srivastava P, Prasad SM, Dubey NK, Chauhan DK, Sahi S. 2018. Acquisition and Homeostasis of Iron in Higher Plants and Their Probable Role in Abiotic Stress Tolerance. Front Environ Sci DOI: 103389/fenvs201700086.

Wu P, Zhao B, Yan J, Luo A, Wu YX, Senadihra D. 1997. Genetic control of seedling tolerance to aluminum toxicity in rice. Euphytica 97: 289293.

Yamaguchi, M and X, Peng. 1993. Ethylene production in rice bronzing leaves induced by ferrous iron. Plant Soil 149: 227-234.

Yang C, Yang L, Yang Y, Ouyang Z. 2004. Rice root growth and nutrient uptake as influenced by organic manure in continuously and alternately flooded paddy soils. Agri Water Manag 70: 67-81.

Yoshida S, Forno DA, James C, Gomez KA. 1976. Laboratory Manual for Physiological Studies of Rice. The International Rice Research Institute. Los Banos, Philippines. 